\title{
5 Ancient Egyptian prescriptions for the back and abdomen and their Mesopotamian and Mediterranean counterparts
}

\author{
Juliane Unger
}

\section{Egyptian sources for renal and rectal diseases ${ }^{1}$}

He will only be able to drink water every three days, whereas it will taste rotten and salty. Finally his body is broken by diarrhoea. ${ }^{2}$

This quotation is part of a text which was intended to promote the profession of the scribe over all other careers, but it also provides us with a vivid, albeit exaggerated, example of a soldier's life and his daily perils, of which diarrhoea was just one problem. We can only assume that internal ailments, caused by polluted water and parasites or by other pathogens, were quite common afflictions in ancient Egypt and therefore commonly dealt with in medical treatises. The textual sources, which could be compiled by their respective scribes from sources of varying age, can be differentiated into essentially two major types of texts. On the one hand, there are the so-called 'Fachbücher', specialised texts, which concentrate on one specific body part ${ }^{3}$ or healing method. ${ }^{4}$ On the other hand, we have so-called 'Sammelhandschriften', collections of many different recipes concerning a wide array of diseases affecting various body parts. ${ }^{5}$ Furthermore, in both of these kinds of manuscripts, we are confronted with several major types of texts describing healing practices and knowledge; only two types will be of interest here. We will look at simple recipes, naming only the treated disease, the ingredients used and their application, and at more elaborate teaching texts, ${ }^{6}$ which list symptoms, describe the patient's condition in detail and provide more detailed information on the treatment. ${ }^{7}$

To illustrate the different levels of knowledge that we can derive from these types of medical texts, especially concerning renal and rectal diseases and their perception in ancient Egypt, a number of significant examples will be given later, beginning with the only two extant specialised texts on that topic, Papyrus Chester Beatty VI (henceforth Bt) and Papyrus Brooklyn 47.218.75+86 (henceforth Brk).

\section{Papyrus Chester Beatty VI}

Papyrus Chester Beatty VI (BM EA 10686), now kept in the Egyptian Gallery of the Great North Museum in Newcastle, was discovered as part of a larger 
group of papyri in 1928 by Bernard Bruyere in the necropolis of Deir el-Medina in Upper Egypt. The private library ${ }^{8}$ it formed part of consisted of at least 38 papyri, which were inscribed with medico-magical texts, hymns and literary texts as well as private letters and treaties. ${ }^{9}$ These papyri were collected over nearly two centuries, from the reign of Ramses II around $1250 \mathrm{BCE}$ to the reign of Ramses IX around 1100 BCE. The scroll of Papyrus Chester Beatty VI, measuring $1.35 \mathrm{~m}$ in length and $21 \mathrm{~cm}$ in height, contains two texts, of which only the medical text on the recto will be of interest here. Dating approximately to $1250 \mathrm{BCE}$, it provides us with eight remaining columns of text comprising 41 recipes, mostly for afflictions of the lower abdomen, the rectum and the anus (Jonckheere 1947).

\section{Bt $13^{10}$}

If it flows out in the form of an influence, with a $b n w$-swelling on the bladder, with stt-mucosities in his joints, with him excreting water from between his buttocks, with his limbs under srf-heat because of the illness, with his urine having run away, his walking is painful, his anus is heavy and there is no end of his discharge. Then you shall say to it: This is a burden of his anus, an illness I will treat. Then you shall make as remedy, so that he recovers: fat of poultry $1 / 64$ oipe, honey $1 / 64$ oipe, human milk 3/64 oipe. Is to be poured into the anus on four days. ${ }^{11}$

\section{Bt 17}

Another remedy for the treatment of the chest, the cooling of the anus, the removal of all his $t 3 w$-heat: green date 1/64 oipe, scratched sycamore fruit $1 / 2$ dja, grapes $1 / 2$ dja, mjmj $1 / 4$ dja, earth almond 1/64 oipe, honey $1 / 4$ dja. Is to be left to the dew overnight, ${ }^{12}$ is to be filtered, (and) is to be taken on four days.

\section{Bt 21}

Another remedy for removing the $k 3 p w$-heat on the heart: green date $1 / 64$ oipe, honey $1 / 4 \mathrm{dja}$, sweet beer $1 / 32$ oipe. Is to be poured into the anus on four days. ${ }^{13}$

Text 13 is one of two surviving short teaching texts in Bt that do not merely name the affliction but describe different symptoms, providing us with a detailed listing of the patient's symptoms. It furthermore gives a diagnosis and a verdict on the chances of recovery. All the other remaining recipes follow the schema illustrated by Texts 17 and 21, which are even shorter in their formulations.

\section{Papyrus Brooklyn 47.218.75+86}

The second object which will concern us here is the yet unpublished Papyrus Brooklyn 47.218.75+86. It is one of many papyri which the American scholar 


\section{Juliane Unger}

and journalist Charles Edwin Wilbour bought in the course of his many travels to Egypt from 1880 to 1896 . After his death, his large private collection came into the possession of the Brooklyn Museum in New York in three bestowals in 1916, 1935 and 1947. Papyrus Brooklyn was part of the latter batch, which alone consisted of 155 scrolls and sheets of papyrus as well as some 100,000 fragments, stored in little carton boxes and envelopes.

As was the case with Bt, the Brooklyn Papyrus formed part of a library, the contents of which can at least in part be reconstructed. There has been a lot of research on this group of texts in recent years (Sauneron 1989; Goyon 1972, 2012; Jasnow 1992; O'Rourke 2015), and some evidence has been collected to place this library on the island of Elephantine in the far south of Egypt (O'Rourke, forthcoming). Brk measured at least 3 metres in length, preserving two specialised medical texts written by two different scribes. The text on the recto consists of approximately 240 recipes for afflictions of the back and abdomen and can be dated to the middle of the 26 th dynasty, around 600 BCE. ${ }^{14}$ One remarkable feature of this text is the localisation of many of the afflictions it treats, namely afflictions of the back and backbone. For comparison: the ancient Egyptian terms for back and backbone, $j 3 t$ and $p s \underline{d}$, were hitherto attested only three times in other medical papyri (von Deines and Westendorf 1961-62). Recipes concerning back pain were altogether unknown until now. The text on the verso is much shorter, preserving 22 recipes focusing on gynaecological problems. It certainly dates later than the text on the recto, but an exact date cannot be determined yet. ${ }^{15}$ Due to the focus of this chapter, the verso of Brk will not be discussed here.

\section{$\operatorname{Brk} \mathbf{x}+\mathbf{2 2}^{16}$}

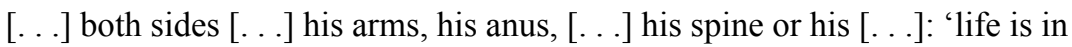
it'-plant [. . .], leaf of Nile acacia $1 / 16 \mathrm{dja}$, is to be finely ground with sweet beer [...] is to be heated, is to be cooled, is to be taken for four days. He shall taste no [bread] or beer whatsoever [...]

\section{Brk x +46}

Remedy for removing every dislocation of the spine, stt-mucosities in both sides of the back: bees wax is to be heated with fat, leaf of Christ's thorn, ${ }^{17}$ $j \check{s} d$ and honey are to be added, he is to be bandaged with it.

\section{Brk x +81}

If you use the $h m m$-tool [ . . ] $1 / 4 \mathrm{dja}[\ldots]$ body part, the big brook of the human $[\ldots]$ milk in it with $w h d w$-pain matters on the underside $[\ldots]^{18}$

Short formulations like those we encountered in recipes 17 and 21 of Bt make up the majority of remedies in Brk, naming only the affliction or disease they were to be prepared for, followed by an enumeration of the drugs which were 
to be used, often with their recommended dosage. Then there are very short instructions for the remedies' preparation and administration. The last recipe is one of the few more elaborate examples found in this text, but its state of preservation is unfortunately quite poor. Its most interesting aspect is the obvious use of a metaphor concerning a body of water. This aspect will be discussed in the following.

Given the brevity of the remedies, it seems appropriate to suppose that texts like Papyrus Bt and Brk were rather used as works of reference by already experienced healers who were able to make a diagnosis on their own. Thus, if an ancient Egyptian healer knew from the symptoms that his patient suffered from the malevolence of some evil spirit of a deceased person, he could find at least eight remedies in Brk to choose from, depending on his experience, the particular symptomatology or the availability of certain drugs.

Directly linked to these short formulations is the question of what we can learn about the afflictions treated here and the concepts surrounding renal and rectal diseases in ancient Egypt. ${ }^{19}$ The problem of retrospective diagnosis is too complex to be discussed here in detail. But since our focus is instead on the concepts that the ancient specialists worked with, the identification of an ancient group of symptoms with a modern disease name would add little to our knowledge (Heeßel 2000: 11; Radestock 2015).

With all due caution, we can however conclude from the combination of certain symptoms and from the recommended therapies that most of the afflictions treated on the recto of Brk must have been internal by modern definition. For most cases, a cause cannot be determined without the risk of interpreting this ancient text on the basis of modern classificatory systems. As far as the text's state of preservation allows an assessment, for the ancient Egyptians whdw-pain substance, stt-mucosities, ${ }^{C}{ }^{C}$-substance and the malevolence of evil spirits ${ }^{20}$ were the most common causes of pain in the back and upper abdomen.

Due to its better state of preservation, Bt provides us with a better overview of the afflictions treated in its recipes. The larger part of them seems to have been external, judging from the symptoms and applied treatments. We can find many recipes naming the symptom $b n w$, which is most commonly translated as ulcer or abscess. Another large group of recipes in $\mathrm{Bt}$ is dedicated to the treatment of different sensations of heat felt in the heart and the rectum. However, apart from the regions of the body where they could be experienced, the recipes do not allow any further conclusions regarding the similarities, differences or causes connected to the different types of heat and other disease terms in ancient Egyptian medical theory. ${ }^{21}$

If we hope to learn more about the concepts behind these afflictions and their treatment, we have to consult other sources. In the recipe collections, we can find a large number of treatments concerning renal and rectal diseases and among them a considerable number of teaching texts relevant for the subject. Therefore, some examples from more elaborate texts will be given in the following pages, which provide us with more information than the specialised texts we have already analysed. 


\section{Papyrus Berlin 3038}

Papyrus Berlin 3038 (short Bln) is part of the collection of the Ägyptisches Museum und Papyrussammlung in Berlin and dates to the New Kingdom around 1250 BCE. Thus, it seems to have been contemporary with Papyrus Chester Beatty VI. The papyrus was found among others in Saqqara by Guiseppe Passalacqua, presumably in 1826, in a clay pot. At least one column of text is missing at the beginning, but the remaining scroll still measures $5.16 \mathrm{~m}$ in length with 21 columns surviving on the recto and three more columns, written in a different hand, on the verso (Westendorf 1999: 41-5).

\section{Bln 154}

Another [remedy for] the nest of the 'roaming of heat': His abdomen is burdened. His stomach hurts. His $j b$-heart is hot and stings. His clothes are a burden for him, he cannot bear many clothes. His $j b$-heart is deranged, he tastes his $h 3 . t j$-heart, which is clouded, like a man who has eaten unripe sycamore fruits. His flesh is weakened, like the flesh of a man who has accomplished the way. ${ }^{22}$ If he sits down to defecate, his anus is burdened because he has no success defecating. Then you shall say to it: One who suffers from a nest of $w h d w$-pain matter in his abdomen, he tastes his hi.tj-heart. An illness which I will treat. If it has become hardened in $\mathrm{it}^{23}$ and a constipation occurs, then you shall make for him remedies for the treatment of $w h d w$-pain matter and remedies for breaking the pain matter in his abdomen: earth almond, finely ground with water five dja, fresh pulp $1 / 8 \mathrm{dja}$, dates in their white form $1 / 4$ dja, juniper berries $1 / 16$ dja, $\underline{d} r n t 1 / 32$ dja, honey $1 / 4$ dja, grapes $1 / 8 \mathrm{dja}, j \check{s} d$ fruit $1 / 8 \mathrm{dja}, j^{c} j$ t-liquid $20 \mathrm{dja}$. (All this) is to be ground finely, (and) to be [drunk] immediately. ${ }^{24}$

\section{Papyrus Ebers}

The next group of examples is taken from the famous medical Papyrus Ebers (short Eb), which is now kept in the Universitätsbibliothek Leipzig. The scroll was acquired by the German Egyptologist Georg Ebers in 1873 in Thebes, but unfortunately its context of discovery is uncertain. It originally measured nearly $20 \mathrm{~m}$ in length and $30 \mathrm{~cm}$ in height, consisted of 108 columns and contained about 880 individual texts and recipes. The palaeography suggests a date for the medical text at about the beginning of the New Kingdom (1550 BCE). Unfortunately, parts of the scroll were lost during World War II (Westendorf 1999: 22-35).

\section{Eb 102}

If you examine someone with stt-mucosities, suffering from cuttings, ${ }^{25}$ his belly is rigid therefrom and he suffers in his stomach: his stt-mucosities are in his belly. They cannot find a way out and since there is no available way 
through which they could go out of it they then putrefy in his belly. They cannot get out and become worms. ${ }^{26}$ They are then completely transformed into worms so that they perish. He then evacuates them, and he immediately gets better. If he does not evacuate them as worms, then you must give him remedies to evacuate, so that he immediately improves.

\section{Eb 193}

If you examine someone with an obstruction in his stomach, ${ }^{27}$ you shall lay your hand on him. If you find his suffering and his swellings shivering if it (the hand) is placed on him with pointed fingers, then you shall say: It is an agglomeration of faeces that has not yet solidified. You shall then prepare for him a herbal remedy: $d \check{s} r . w$-part of $m n \underline{d} j$-plant $11 / 2$ dja, cooked (in) oil and honey, ${ }^{c}{ }^{c} m$-plant $1 / 16 \mathrm{dja}$, 'hair'-fruit $1 / 16 \mathrm{dja}, \check{s} 3 \check{s} 3$-fruits $1 / 8 \mathrm{dja}, \mathrm{gjw}$ of the lake $1 / 16 \mathrm{dja}$, gjw of the garden $1 / 16 \mathrm{dja}$, wine, milk, eaten, swallowed with sweet beer, so that he gets well immediately.

\section{Eb 200}

If you examine a man who suffers from his stomach and you find it (the disease) on his back like one stung, then you shall say to it: there are pain-matters that are damaging his back, a disease that I will treat with an after-treatment. Go against it! Do not run away! You shall prepare against it: hmt-agents of $\underline{d} s f$ and administer an after-treatment: $h t$ - $d s$-tree 1, nj3j3-plant 1, leaves of acacia $1, b s n$-salt of the bricklayer 1 , is to be ground, is to be cooked in dregs of sweet beer. $\mathrm{It}^{28}$ is to be bandaged with it on four days so that he gets well immediately.

\section{Eb 204}

If you examine someone with an obstruction in his left side, and if it is found under his side and does not cross the land, ${ }^{29}$ then you shall say to it: it has made a shore, it has built up a sand-bank. ${ }^{30}$ Then you shall prepare a remedy of its . . . ${ }^{31}$ beginning (? $)^{32}$ consisting of ground $p s \underline{d} 1 / 4 \mathrm{dja}, t j{ }^{c} m$-plant $1 / 8$

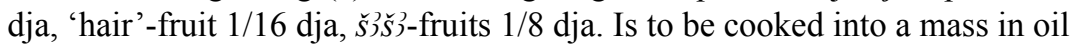
$2 / 3 \mathrm{dja}$ and honey $1 / 3 \mathrm{dja}$. It is to be eaten by the man on four days. If you examine him afterwards and find that it has expanded (and) gone downwards, then you shall prepare for him a powder of $p s \underline{d}$, thoroughly cooked. Is to be eaten by the man on four days in order to fill his belly, in order to bend his intestine. Then you shall lay your hand on him. Should you find it cut down in pieces (and) milled like something from harvested wheat, ${ }^{33}$ then you should prepare an instant-drink for cooling: $m j m j$-grain $1, j w h$-fruits 1 , water, is to be strained, (and) to be drunk on four days. ${ }^{34}$

From these and other teaching texts in Bln and Eb, we can conclude that the quite common $w h d w$-pain matters and stt-mucosities were pathogenic substances that were thought to be caused by disturbances of normal digestion. As we know from 
other texts, these pathogenic substances could then move through the body via the $m t w$-vessels, which were thought to connect organs and body parts and to transport water, air, urine, faeces and other pathogenic substances. There is no modern anatomical term that completely comprises the wide semantic spectrum the ancient Egyptians ascribed to $m t w$ (Pommerening 2010: 154). It was believed that heart and rectum were directly connected by $m t w$, which explains the numerous recipes treating symptoms of both body parts as well as symptoms of the heart via enemas, especially in Bt. If too much whdw and stt accumulated in the body, pain, certain sensations of heat and other disorders were the natural consequence, as is vividly shown by recipe no. 154 of Bln and no. 102 of Eb. ${ }^{35}$

Yet the analysis of certain texts or recipes on the basis of other sources has to be made with special caution. We have to keep in mind that, for example, about a millennium lies between the writing down of Brk and Eb, so we have to tread carefully when interpreting the former on basis of the latter. Glosses explaining older or antiquated terms are a good reminder that even the ancient Egyptians already had problems reading and interpreting their own texts and tried to solve them with these annotations. ${ }^{36}$ We simply cannot exclude the possibility that, like the technical terms, certain anatomical concepts changed over time. If we could isolate them, those changes might be minimal. But according to Joachim Friedrich Quack, we should not assume that the ancient Egyptians had one single universal concept for the causes of all diseases throughout their history. They might have been open-minded and flexible about the different possible causes of different afflictions. Furthermore, it seems that their main focus had always been to find the right treatment for the individual cases, rather than developing an allencompassing theoretical framework for all diseases (Quack 2003: 13).

\section{Theoretical background for cross-cultural comparisons}

The second part of this study will reach out to the Mesopotamian and Mediterranean evidence of recipes for abdominal conditions and compare them with the Egyptian examples discussed in the previous paragraphs. Of course, the most important question in this respect is whether we can detect a possible transfer of medical knowledge between the cultures of this geographical area.

This analysis will mainly rely on the methodological principles stated by Meir Malul in The Comparative Method in Ancient Near Eastern and Biblical Legal Studies. ${ }^{37}$ For our purpose, Malul's 'historical comparison approach' is of importance, particularly the comparison of cultures of the same 'historic stream'. Within this framework, comparisons are based on the assumption of a historical connection or of a common tradition shared by the cultures being compared. In this respect, the copying of important texts over long periods of time - as was the usual case in Egypt and Mesopotamia - reduces the problems involved in comparing texts dating to chronologically distant periods (Malul 1990: 13).

Malul states five main factors for well-grounded comparisons: (1) conclusive proof of historical relationships between the compared cultures (Malul 1990: 22); (2) the goal and specialities of the comparison have to be made clear and detected 
differences, equalities and parallels have to be analysed, not just named (Malul 1990: 32); (3) every scientist working with such comparisons should always take a close look at the opposite culture as well, in order to gain a deeper understanding of 'the type of connection, the attitude of the borrowing culture toward the borrowed phenomenon, and the way it might have reworked and adapted it' (Malul 1990: 47); (4) every identified phenomenon that might hint at a transfer of knowledge should also be analysed with respect to singularity versus coincidence, meaning that we have to find out whether there could just have been independent and parallel evolutions or whether there really was some degree of exchange or adaptation (Malul 1990: 93); and (5) there is the question of the kind of contact, whether it occurred only indirectly, through texts or through direct contact. One has to ask whether the author of a certain textual source borrowed the phenomenon in question from another written source or whether he was thoroughly integrated in a medical culture shared throughout the ancient Near East, letting parts of his life's experience become part of the text. Of course, these variants do not exclude each other, especially not in the case of a collection of medical recipes (Malul 1990: 83-4).

Furthermore, Malul differentiates four possible types of connection between text sources ${ }^{38}$ (Malul 1990: 89-91), but since detailed information of the kind needed for this analysis is almost impossible to obtain from collections of medical recipes, which in themselves do not attribute any theoretical background concerning the treated afflictions, the question of how the texts under scrutiny here might have been related cannot be discussed. Nevertheless, Malul's factors for comparison, as stated earlier, prove highly useful as a systematic background, when in the next section we take a look at renal and rectal disease texts in Mesopotamia and the Mediterranean and their possible connection to Egyptian sources.

\section{Renal and rectal disease texts in Mesopotamia and the Mediterranean}

In what follows, I will present some possible points of comparison between Egyptian recipes for renal and rectal diseases and their equivalents in other Mediterranean cultures. Cultural contacts between Egypt and its neighbours can be traced back to predynastic times and there are several sources of certain evidence for the transfer of medical knowledge and even the exchange of medical personnel, which was by no means unidirectional. ${ }^{39}$

Several letters sent from the Ramesside court to the Hittite court have been preserved in the archives of Hattuša which provide us with reliable and vivid evidence for the exchange of healers and drugs between these empires, roughly contemporary with the manufacture of Bln and Bt (Edel 1976). With the wellknown statue of the healer Udjahoresne, we have proof from a later period for an Egyptian healer at the Persian court, and it seems very likely that he was not the only one brought there in the course of Assyrian deportation policies. ${ }^{40}$ The contact of Egypt with Crete and the Greek mainland is archaeologically proven from the middle to late Bronze Age onwards, and certain sources hint at the existence 
of a circular trade route connecting the Aegean and the Eastern Mediterranean for the period around $1400 \mathrm{BCE}$ to $1100 \mathrm{BCE}$. These contacts intensified over the course of time with the founding of the city of Naukratis in the seventh to sixth century BCE and the numerous Greek mercenaries in service of the rulers of the Saitic period as just two aspects of this (Lloyd 2000: 365-9). Therefore, Malul's first condition of proven cultural contact can easily be ascertained. The overall situation is summed up best by Eric Cline's statement:

The Late Bronze Age physical artefacts, along with the textual references, the inscriptions, and the wall paintings found in the Aegean and Eastern Mediterranean, indicate that we must envision strong commercial and cultural interactions between the Mycenaean and Minoans and the Canaanites, Kassites, Mitanni, Cypriotes, Assyrians, Egyptians, Italians, Sardinians, Sicilians, and, to a lesser extent, even the Hittites.

(Cline 1994: 107)

The few surviving medical texts of the Hittites unfortunately offer few points for comparison with Egyptian recipes for renal and rectal diseases, though in this case we know of a direct exchange of medical practitioners and drugs. Hittite recipes are composed in a very similar form when compared to their Egyptian counterparts. At the beginning of a prescription, the name of the disease, symptoms and, in some cases, the afflicted organs are given. Then the drugs to be used, their processing and the application instructions are listed. At the end of the prescriptions, we can often find the formula 'he will recover' or alternative recipes if the first treatment was not successful (Burde 1974). Although this structure is very similar to the Egyptian prescriptions, it can be found in many recipes from Mesopotamia as well. It seems plausible to regard this phenomenon as a case for the problem of chance versus singularity. The recipe structure of Hittite medical texts does not necessarily need an Egyptian influence to be logical in the eyes of a Hittite healer and could well be compared with Mesopotamian recipes.

If we take a look at Babylonian and Assyrian tablets concerning renal and rectal diseases, which have been published by Markham Geller (2005), we can detect certain similarities between symptoms, treatments and afflictions. ${ }^{41}$ Therapeutic strategies such as enemas, ointments, bandages etc. are quite common in both healing traditions, but given the shared topic and the similarities between both geographical regions and their climate, this is not conclusive evidence that there was a transfer of medical knowledge. One major difference as far as application methods are concerned is the treatment of many afflictions of the kidneys and the bladder by blowing a remedy into the urethra via a small bronze or copper tube in Babylonian-Assyrian remedies. This application method seems hitherto unknown in Egyptian renal recipes and cannot be found in the younger Brooklyn text. If this treatment ever appears in a later medical text from Egypt, it could be a hint at some Mesopotamian influence. Many recipes for renal and rectal diseases from Mesopotamia prescribe oral remedies to be taken on an empty stomach. It 
is interesting that only two recipes from Brk could be interpreted in this respect and none in Bt contains a comparable instruction. ${ }^{42}$ Unfortunately, these facts leave much room for speculation and a straightforward interpretation is hard to advance.

The most striking difference between Egyptian and Mesopotamian medicine seems to be the fact that we cannot find anything in Babylonian and Assyrian texts that could be compared with the Egyptian theory concerning the pathogenic substances $w h d w$ and stt and their impact on the human body. We can only speculate about the reason for this striking disparity - be it chance or a remarkable divergence between Mesopotamian and Egyptian disease concepts and aetiological models. ${ }^{43}$ The following Mesopotamian text examples illustrate the differences to the Egyptian texts discussed earlier.

\title{
BAM 95, lines 19-20
}

If a man pulsates in his shins, is constipated, and he is wasting away, his blood drains away, that man is ill in the anus, (it is) Hand of Oath - to cure him, crush together nink $\hat{u}$, sahl $\hat{u}$, and horned alkali, mix (them) in fat, [make] a suppository and put it into his anus [and he will improve].

$(\text { Geller 2005: 131) })^{44}$

\section{BAM 95, lines 27-28}

If a man suffers from a diseased anus, defecates blood and the middle of his rectum 'hastens', to [heal him], mix baluhhu, kanaktu, date-rind in fat, make a suppository, put it into his anus (var. and he will improve).

$(\text { Geller 2005: 131) })^{45}$

\begin{abstract}
AMT 45.5 (K 5416a)
Incantation. 'The canal is cut through, the irrigation ditch flows over, a breech has been made by the violent flood. The stopper of the fermenting vessel has fallen (out), NN, son of NN, has diarrhoea (lit. "his gut has fallen"), it has no halt!'
\end{abstract}

(Steinert 2013:12-3; Böck 2014: 101-3) ${ }^{46}$

The last example, from a Neo-Assyrian (ca. 911-612 BCE) tablet from Nineveh, ${ }^{47}$ is a very interesting incantation, which uses a number of metaphors of bodies of water in relation to a case of diarrhoea. We encountered a seemingly similar case in recipe $x+81$ from Brk. Unfortunately, the latter passage is severely damaged and we cannot conclude much more from it than that there was a metaphorical use of the Semitic loan word for 'brook' $(y b r)^{48}$ in the context of a medical recipe that was most likely directed towards a rectal disease or abdominal pain. But although the evidence is by far too scarce to propose any kind of connection and although the use of river metaphors in both medical traditions is not surprising, given how 


\section{2}

much these regions are dependent on their rivers, it still poses an interesting field for further and more detailed research. ${ }^{49}$

It should be obvious by now that however similar the Babylonian-Assyrian recipes appear to their Egyptian counterparts in terms of structure or treated symptoms, none of the examples presented provides evidence that is strong enough to prove any kind of substantial cross-cultural influence between Egypt and Mesopotamia in the realm of renal and rectal disease recipes. Of course, we still have the problem that it seems appropriate to assume for medicinal recipes that a lot of knowledge transfer might have been concentrated on the use of certain plants and other drugs. Since we mostly lack indisputable identifications of many ingredients in Egyptian and Mesopotamian texts, it is difficult to trace potential transfers, if their names have been translated or if they are not commented on as foreign imports, for example. ${ }^{50}$

A last short glance will be directed towards the Aegean..$^{51}$ The great appreciation Greek healers and historians had for Egyptian medicine is commonly known. This is further proved by the numerous drugs and plants that are called 'Egyptian' in Graeco-Roman pharmacology, found in the Corpus Hippocraticum, Plinius, Galen, Dioscorides and Herophilus. According to the Index Hippocraticum, 'Egyptian' is by far the most common named origin for ingredients. One can only assume that part of the appreciation for those ingredients was due to their rarity and distant, exotic origin (Thomas 2004: 183). But, as in the case of exchanges between Egypt and Greece, we are confronted with the problem of secure identifications for the materia medica.

One of the most intriguing and most discussed aspects connecting Egyptian and Greek medicine might be the possible influence that the Egyptian aetiological theory concerning the pathogenic substances $w h d w$ and stt might have had on Greek humoral pathology (Steuer and Saunders 1959). Since both substances are among the primary reasons for renal and rectal diseases according to ancient Egyptian belief, this theory cannot be left unmentioned in this context. Robert Steuer and John Saunders provided a comprehensive study on this possible knowledge transfer and came to the conclusion that

the opinions of the founder of the Cnidian school, Euryphon, as expressed in Papyrus Anonymus Londinensis, represent only the crudest expressions of limited aspects of the aetiological theory of $w h d w$. It is impossible to determine whether he obtained these views by hearsay or from written sources.... However, the most immediate connecting link between Ancient Egyptian and Cnidian aetiology is the belief in the rising of fecal excrements in the body as the primary cause of disease and, intimately related to this belief, fundamental views on putrefaction that in turn lie at the root of the early perittoma concept.

(Steuer and Saunders 1959: 54) $)^{52}$

The situation we are faced with in the analysis of possible connections between Egyptian, Mesopotamian and Greek medicine and their influences on one another has best been summed up by Rosalind Thomas, saying: 
Trading spheres and contacts cannot by themselves indicate any certain exchange of intellectual ideas or theories, ... . but it is striking that the Hippocratic medical works show some confluence between theoretical speculation and the distant areas which provided some of the most exotic drugs ...-ideas and ingredients perhaps travelling together.

(Thomas 2004: 185) $)^{53}$

In every search for points of comparison between Egyptian and Mesopotamian or between Egyptian and Greek medicine, we always have to keep in mind that commonly used materia medica are almost never a useful foundation to propose a knowledge transfer based on their shared, empirical medicinal use. This could well be due to parallel and unconnected developments and experiences. Direct influences are far easier to detect in the area of medical theories, diagnostics and therapeutic methods calling for complex actions, incantations and precise applications. Unfortunately, such extensive recipes seem to be relatively rare among renal and rectal disease texts from all cultures reviewed here. In Brk we find a number of foreign words fully integrated among the familiar Egyptian drugs, but without identifications we cannot determine their exact origin in foreign healing traditions. There even is at least one example for the use of a Persian weight unit in an otherwise unremarkable recipe, which is unfortunately badly damaged and therefore eludes further interpretation for now. ${ }^{54}$ Despite the considerable number of recipes and their thematic specialisation, neither Bt nor the much later Brk provide sufficient clues for determining the detailed processes of knowledge transfer Malul has established.

Maybe even Papyrus Brooklyn 47.218.75+86 is just a few years too old and still too much integrated in the Egyptian healing tradition to show foreign influences in this very specialised field of medicine to the extent encountered in Hellenistic and later texts. According to Friedhelm Hoffmann, Papyrus Vienna D 6257 from the Roman era contains numerous names of new plants and minerals given by their Semitic or Greek terms written in Demotic script, as well as more evidence for the use of the Persian metric unit already found in Brk. ${ }^{55}$ Further research into this papyrus and other, still unpublished Demotic medical texts will show whether this late text group can provide us with more conclusive evidence for the transfer of knowledge concerning renal and rectal diseases between Egypt and its neighbours.

\section{Notes}

1 I wish to thank the organisers for the invitation to contribute to this volume. Further thanks go to Ulrike Steinert for fruitful discussions and priceless help concerning loanwords.

2 The passage stems from Papyrus Lansing 10.1-10.2; the translation follows Tacke (2001: 104).

3 See for example Papyrus Brooklyn 47.218.49 for the protection of the ears of the pharaoh (O'Rourke 2015).

4 See e.g. Papyrus Edwin Smith with a focus on chirurgical problems and procedures. 


\section{Juliane Unger}

5 Examples for those would be Papyrus Ebers, Hearst, etc.

6 For a detailed discussion of teaching texts see Pommerening (2014).

7 See the chapter by Susanne Radestock in this volume.

8 The papyri were deposited in a tomb chapel in the necropolis, when they were of no more use to their owners. They were not found as mortuary goods in the grave itself. If we aimed at a classification for this collection of texts, we might best call it a library with archival character. For a description of the discovery see Bruyere (1929); Koenig (1981: 41-3).

9 It is highly interesting that a text like Papyrus Chester Beatty VI, recto formed part of such a private library. One can hardly suppose that it was only read for fun. Since the owners of the library were no physicians but mere scribes of the necropolis, we cannot determine what use they made of it. See also Pestman (1982: 155-72).

10 The first word of the recipes as well as measurements are often written in red ink in Egyptian medical texts and are rendered here by underlining. The measurement unit dja has a volume of $300 \mathrm{ml}$ and equals 1/64 of the oipe unit. The different units are separated by the way in which the numerals were written. The absence of measurements in certain recipes does not necessarily mean that the ingredients were to be used in equal amounts. It could as well mean that the respective healer knew the dosages from experience. For a detailed study see Pommerening (2003).

11 For the identification of Egyptian materia medica used in these examples, see among others von Deines and Grapow (1959); Manniche (1989); Germer (2008).

12 There is a similar instruction in Mesopotamian texts: 'you leave (a medication outside) over night with the star(s)' (Akk. ina kakkabi tušbât). However, the Egyptian instruction is lacking any definite stellar reference. See also Ritner (2000: 112).

13 Translations are by the author.

14 The dating is according to the extensive palaeography of Verhoeven (2001).

15 The later date of this text can be ascertained by its relation to the text on the recto.

16 The reconstruction of Brk is not yet finite, and therefore the numbering of the recipes might still be subject to revision.

17 The Egyptian term is $n b s$ and the identification as Zizyphus spina-Christi Willd. seems to be quite certain. See Germer (2008: 83-4); Manniche (1989: 157-8).

18 Due to the recipe's poor state of preservation, its exact meaning remains obscure. In $\mathrm{Eb} 865 \mathrm{c}$, the hmm-tool is used to open a certain swelling on the patient's body. Thus, a similar disease might have been treated here as well. The role of milk and $w h d w$ cannot be determined. Translations are by the author.

19 The term 'concept' is understood here according to the definition given by Pommerening (2017a: 168).

20 Concerning these entities see also the chapter by Rune Nyord in this volume.

21 The manner of manufacture and the use of certain drugs can also shed light on underlying concepts of illness and recovery, but this approach is not without difficulties since the best results will be obtained by the actual recreation of the recipes. See Pommerening (2017a: 183, 2017b).

22 For this formulation see also Eb 855x, where it is explained that this comparison refers to a man who is tired from walking a long distance.

23 'It' refers to the patient's abdomen.

24 Translation by the author.

25 This most likely refers to a specific kind of pain. The word is presumably derived from the verb $n q^{c}$ 'to cut'.

26 Ulrike Steinert drew my attention to a similar disease named urbatu in Mesopotamian texts, which sometimes refers to a worm and occurs in the context of abdominal and rectal ailments. However, this disease is not connected to putrefaction of abdominal matter. See CAD U/W sub urbatu B for references, e.g. Geller (2005: No. 34: 1 and 27: 18) or Scurlock (2014: 495-8). 
27 Ulrike Steinert pointed out to me a similar disease term in Mesopotamian texts: kīs libbi 'bond of the belly' (meaning the inability to ingest food).

28 'It' here refers to the affected part of the body.

29 This phrase is unique in Egyptian medical texts but is attested in other sources with the meaning 'to cross a land'. Walker (1996: 137) proposes several interpretations but the overall meaning seems to be that the illness affects only one side of the body.

30 This passage remains quite obscure, yet the used metaphors related to a body of water are remarkable.

31 This part of the line is left empty.

32 'Beginning' here seems to refer to the obstruction, possibly meaning an early stage of the illness. See also Radestock (2015: 154).

33 When the healer uses palpation in order to determine certain symptoms, metaphorical descriptions and comparisons like this, characterising what exactly he was about to feel, are quite common in the teaching texts. See also Radestock (2015: 287-96) for semiotics in Egyptian medical texts.

34 Translation by the author.

35 For a comprehensive overview of aetiological systems in Egyptian medicine see Stephan (2007).

36 A striking example for a medical text featuring extensive glosses is Papyrus Edwin Smith. See also the great online presentation of this text at https://ceb.nlm.nih.gov/proj/ ttp/flash/smith/smith.html (accessed 7 July 2017).

37 Although he aims at a very different group of texts, the criteria he has established prove useful in the search for cross-cultural relations in other text genres.

38 The four types are: (1) direct dependence of source B on source A; (2) 'mediated connection', meaning that source B is not directly dependent on source A, but on source $\mathrm{C}$, which is directly dependent on source $\mathrm{A}$ (whereby source $\mathrm{C}$ can comprise more than one single source); (3) the compared sources B and C are both dependent on source A; (4) the compared sources exhibit similar traits and could be part of a common tradition.

39 For an overview of the evidence for knowledge transfer in other branches of Egyptian medicine see Ritner (2000, 2007). See also Couto-Ferreira (2013) for an overview on the flow of medical practitioners in the ancient Near East during the Late Bronze Age.

40 For an overview and further literature see Baines (1996); Radner (2009).

41 Medical texts equalling the diagnostic handbooks of Mesopotamia are not known from Egypt and therefore the latter will not be discussed here.

42 Another dietary instruction can be found in $\mathrm{Eb} 189$ which instructs the healer to keep the patient from eating roasted meat.

43 Note further Gordon and Schwabe (2004: 186), who propose that because of the earlier separation of medical practitioners of human and veterinary medicine and due to the different specialists in charge of animal- or organ divination, healing and rituals in Mesopotamia (as opposed to ancient Egypt or Greece) 'there seemed to have been fewer opportunities . . . for individual healers of people to personally make comparative biomedical observations on animals or benefit from ones made by others'. For an analysis of the body concepts inherent in the Mesopotamian medical texts, see Steinert (2016).

44 The symptoms described in this recipe show some similarity to recipe no. 13 of Bt. Nevertheless, the ingredients differ as far as can be told, and the passages are not sufficient for a proper comparison.

45 Translation by M. J. Geller.

46 Translation by U. Steinert. Of course, this incantation is also a great example of simile magic.

47 See the Cuneiform Digital Library Initiative (CDLI), P396019 for an overview and a transliteration.

48 See Hoch (1994: 50-1 (49)), $y b r=$ 'stream', connected to the Semitic root $y b l$ 'to flow'. 
49 A good overview and in-depth study of the Mesopotamian perspective can be found in Steinert (2017).

50 For an initial study that traces cross-cultural exchanges of medical remedies from Mesopotamia to Egypt by focusing on an identified drug (pomegranate root), see Pommerening and Steinert (2019).

51 For an overview of possible relations between Greek and Mesopotamian medicine see Stol (2004); Asper (2015).

52 The concept of perittoma in Cnidian medicine seems to be directly derived from the Egyptian concept of $w h d w$ roaming in the body. See also a summary of the topic in Stephan (2011: 5-7).

53 Another good summary for the amount and ways of knowledge transfer between the cultures of the Mediterranean in the Bronze Age can be found in Arnott (2004).

54 pBrooklyn 47.218.75+86, unnumbered fragment.

55 A new edition of this papyrus is prepared by F. Hoffmann (forthcoming). See also Hoffmann and Quack (2010: 300-5); Hoffmann (2010: 201-18). The first edition by Reymond (1976) is to be used with much caution only.

\section{References}

Arnott, R. (2004) 'Minoan and Mycenaean Medicine and Its Near Eastern Contacts', in Horstmanshoff, H. F. J. and Stol, M. (eds.) Magic and Rationality in Ancient Near Eastern and Graeco-Roman Medicine. Leiden/Boston: Brill, 153-73.

Asper, M. (2015) 'Medical Acculturation? Early Greek Texts and the Question of Near Eastern Influence', in Holmes, B. and Fischer, K.-D. (eds.) The Frontiers of Ancient Science: Essays in Honor of Heinrich von Staden. Beiträge zur Altertumskunde 338. Berlin/New York: de Gruyter, 19-46.

Baines, J. (1996) 'On the Composition and Inscriptions of the Vatican Statue of Udjahorresne', in Der Manuelian, P. (ed.) Studies in Honour of William Kelly Simpson. Vol. 1. Boston: Department of Ancient Egypt, Nubian, and Near Eastern Art, Museum of Fine Arts, 82-92.

Böck, B. (2014) The Healing Goddess Gula: Towards an Understanding of Ancient Babylonian Medicine. Leiden/Boston: Brill.

Bruyere, B. (1929) Rapport sur les Fouilles de Deir el Medineh/1928. Fouilles de l'Institut Français d'Archéologie Orientale 6, 2. Kairo: L'Institute Français d'Archéologie Orientale.

Burde, C. (1974) Hethitische medizinische Texte. Studien zu den Boğazköy-Texten 19. Wiesbaden: Harrassowitz.

Cline, E. H. (1994) Sailing the Wine-Dark Sea: International Trade and the Late Bronze Age Aegean. British Archaeological Reports International Series 591. Oxford: Archaeopress.

Couto-Ferreira, E. (2013) 'The Circulation of Medical Practitioners in the Ancient Near East: The Mesopotamian Perspective', in Carro Martín, S. et al. (eds.) Mediterráneos: An Interdisciplinary Approach to the Cultures of the Mediterranean Sea. Newcastle upon Tyne: Cambridge Scholars Publishing, 401-16.

Edel, E. (1976) Ägyptische Ärzte und ägyptische Medizin am hethitischen Königshof. Rheinisch-Westfälische Akademie der Wissenschaften Band 205. Opladen: Westdeutscher Verlag.

Geller, M. J. (2005) Renal and Rectal Disease Texts. Die babylonisch-assyrische Medizin in Texten und Untersuchungen Band VII. Berlin/New York: de Gruyter.

Germer, R. (2008) Handbuch der altägyptischen Heilpflanzen. Philippika 21. Wiesbaden: Harrassowitz. 
Gordon, A. H. and Schwabe, C. W. (2004) The Quick and the Dead: Biomedical Theory in Ancient Egypt. Egyptological Memoirs 4. Leiden/Boston: Brill/Styx.

Goyon, J.-C. (1972) Confirmation du pouvoir royal au Novel An. Bibliothèque d'Étude 52. Kairo: Institut Français.

Goyon, J.-C. (2012) Le recueil de prophylaxie contre les aggressions des animaux venimeux du Musée de Brooklyn, Papyrus Wilbour 47.218.138. Studien zur spätägyptischen Religion 5. Wiesbaden: Harrassowitz.

Heeßel, N. P. (2000) Babylonisch-assyrische Diagnostik. Alter Orient und Altes Testament 43. Münster: Ugarit-Verlag.

Hoch, J. E. (1994) Semitic Words in Egyptian Texts of the New Kingdom and Third Intermediate Period. Princeton: Princeton University Press.

Hoffmann, F. (2010) 'Zur Neuedition des hieratisch-demotischen Papyrus Wien D 6257 aus römischer Zeit', in Imhausen, A. and Pommerening, T. (eds.) Writings of Early Scholars in the Ancient Near East, Egypt, Rome, and Greece: Translating Ancient Scientific Texts. Beiträge zur Altertumskunde 286. Berlin/New York: de Gruyter, 201-18.

Hoffmann, F. (forthcoming) Die spätägyptischen medizinischen Papyri aus der Österreichischen Nationalbibliothek. Mitteilungen aus der Papyrussammlung der Österreichischen Nationalbibliothek (Papyrus Erzherzog Rainer), Neue Serie. Berlin/New York: de Gruyter.

Hoffmann, F. and Quack, J. F. (2010) 'Demotische Texte zur Heilkunde', in Janowski, B. and Schwemer, D. (eds.) Texte aus der Umwelt des Alten Testaments, Neue Folge Band 5. Texte zur Heilkunde. Gütersloh: Gütersloher Verlagshaus, 298-316.

Jasnow, R. L. (1992) A Late Period Hieratic Wisdom Text (P. Brooklyn 47.218.135). Studies in Ancient Oriental Civilization, No. 52. Chicago: The Oriental Institute of the University of Chicago.

Jonckheere, F. (1947) Le papyrus médical Chester Beatty. Brüssel: Édition de la Fondation Égyptologique Reine Élisabeth.

Koenig, Y. (1981) 'Notes sur la découverte des papyrus Chester Beatty', Bulletin de l'Institut Français d'Archéologie Orientale 81 (Kairo/Paris: Ministère de l'Education National de la Recherche et de la Technologie), 41-3.

Lloyd, A. B. (2000) 'The Late Period (664-332 BC)', in Shaw, I. (ed.) The Oxford History of Ancient Egypt. Oxford: Oxford University Press, 364-87.

Malul, M. (1990) The Comparative Method in Ancient Near Eastern and Biblical Legal Studies. Alter Orient und Altes Testament 227. Kevelaer/Neukirchen-Vluyn: Butzon \& Bercker/Neukirchener Verlag.

Manniche, L. (1989) An Ancient Egyptian Herbal. London: British Museum Publications Limited.

O'Rourke, P. F. (2015) A Royal Book of Protection of the Saite Period: pBrooklyn 47.218.49. Yale Egyptological Studies 9. New Haven: Yale Egyptological Institute.

O'Rourke, P. F. (forthcoming) 'Charles Edwin Wilbour and the Provenance of his Papyri', in Lepper, V. (ed.) Essays on Elephantine.

Pestman, P. W. (1982) 'Who Were the Owners, in the "Community of Workmen", of the Chester Beatty Papyri', in Demarée, R. J. (ed.) Gleanings from Deir el-Medina. Egyptologische Uitgaven 1. Leiden: Nederlands Instituut voor het Nabije Oosten, 155-72.

Pommerening, T. (2003) 'Neues zu den Hohlmaßen und zum Medizinalmaßsystem', in Bickel, S. and Loprieno, A. (eds.) Basel Egyptology Prize 1: Junior Research in Egyptian History, Archaeology, and Philology. Aegyptiaca Helvetica 17. Basel: Schwabe, 201-19. 
Pommerening, T. (2010) 'Von Impotenz und Migräne - eine kritische Auseinandersetzung mit Übersetzungen des Papyrus Ebers', in Imhausen, A. and Pommerening, T. (eds.) Writings of Early Scholars in the Ancient Near East, Egypt, Rome, and Greece: Translating Ancient Scientific Texts. Beiträge zur Altertumskunde 286. Berlin/New York: de Gruyter, 153-74.

Pommerening, T. (2014) 'Die $\check{s} s 3$-Lehrtexte der heilkundlichen Literatur des Alten Ägypten', in Bawanypeck, D. and Imhausen, A. (eds.) Traditions of Written Knowledge in Ancient Egypt and Mesopotamia: Proceedings of Two Workshops Held at GoetheUniversity, Frankfurt/Main in December 2011 and May 2012. Alter Orient und Altes Testament 403. Münster: Ugarit-Verlag, 7-46.

Pommerening, T. (2017a) 'Classification in Ancient Egyptian Medical Formulae and Its Role in Re-Discovering Comprehensive and Specific Concepts of Drugs and Effects', in Bisang, W. and Pommerening, T. (eds.) Classification from Antiquity to Modern Times: Sources, Methods, and Theories from an Interdisciplinary Perspective. Berlin/Boston: de Gruyter, 167-95.

Pommerening, T. (2017b) 'Medical Re-Enactments: Ancient Egyptian Prescriptions from an Emic Viewpoint', in Rosati, G. and Guidotti, M. C. (eds.) Proceedings of the XI International Congress of Egyptologists, Florence Egyptian Museum, 23-30 August 2015. Archaeopress Egyptology 19. Oxford: Archaeopress Publishing Ltd, 519-26.

Pommerening, T. and Steinert, U. (2019) 'Hilfreiche Rezepte überschreiten Grenzen - Zur Behandlung von Würmern mit der Granatapfelwurzel im Alten Ägypten und Mesopotamien', in Schubert, A., Leitmeyer, W. and Zanke, S. (eds.) Medicus: Die Macht des Wissens. Begleitkatalog zur Sonderausstellung. Speyer: Historisches Museum der Pfalz, 54-5.

Quack, J. F. (2003) 'Methoden und Möglichkeiten der Erforschung der Medizin im Alten Ägypten', Medizinhistorisches Journal 38, 3-15.

Radestock, S. (2015) Prinzipien der ägyptischen Medizin, Medizinische Lehrtexte der Papyri Ebers und Smith: Eine wissenschaftstheoretische Annäherung. Wahrnehmungen und Spuren Altägyptens 4. Würzburg: Ergon Verlag.

Radner, K. (2009) 'The Assyrian King and His Scholars: The Syro-Anatolian and the Egyptian Schools', in Luukko, M. et al. (eds.) Of God(s), Trees, Kings, and Scholars: Neo-Assyrian and Related Studies in Honour of Simo Parpola. Studia Orientalia 106. Helsinki: Suom. Kirj. Seuran Kp., 221-38.

Reymond, E. A. E. (1976) From the Contents of the Libraries of the Suchos Temples in the Fayum. I: A Medical Book from Crocodilopolis. P. Vindob. D 6257. Mitteilungen aus der Papyrussammlung der Österreichischen Nationalbibliothek (Papyrus Erzherzog Rainer), Neue Serie 10. Berlin/New York: de Gruyter.

Ritner, R. K. (2000) 'Innovations and Adaptations in Ancient Egyptian Medicine', Journal of Near Eastern Studies 59, 107-17.

Ritner, R. K. (2007) 'Cultural Exchanges between Egyptian and Greek Medicine', in Kousoulis, P. (ed.) Moving across Borders: Foreign Relations, Religion and Cultural Interactions in the Ancient Mediterranean. Orientalia Lovaniensia Analecta 159. Leuven: Peeters, 209-21.

Sauneron, S. (1989) Un traité égyptien d'Ophiologie. Bibliothèque générale 11. Kairo: L'Institut Français d'Archéologie Orientale.

Scurlock, J. (2014) Sourcebook for Ancient Mesopotamian Medicine. Writings from the Ancient World 36. Atlanta: SBL Press.

Steinert, U. (2013) 'Fluids, Rivers, and Vessels: Metaphors and Body Concepts in Mesopotamian Gynaecological Texts', Le Journal des Médecines Cunéiformes 22, 1-23. 
Steinert, U. (2016) 'Körperwissen, Tradition und Innovation in der babylonischen Medizin', in Wulf, C. and Renger, A.-B. (eds.) Körperwissen: Transfer und Innovation (Paragrana: Internationale Zeitschrift für Historische Anthropologie 25/1). Berlin: de Gruyter, 195-254.

Steinert, U. (2017) 'Concepts of the Female Body in Mesopotamian Gynecological Texts', in Wee, J. Z. (ed.) The Comparable Body: Analogy and Metaphor in Ancient Mesopotamian, Egyptian, and Greco-Roman Medicine. Leiden/Boston: Brill, 275-357.

Stephan, J. (2007) 'Die anatomischen, physiologischen und pathophysiologischen Grundlagen der ägyptischen Krankheitslehre', in Hannig, R., Vomberg, P. and Witthuhn, O. (eds.) Marburger Treffen zur altägyptischen Medizin. Vorträge und Ergebnisse des 1.-5. Treffens 2002-2007. Göttinger Miszellen, Beihefte, Nr. 2. Göttingen: Seminar für Ägyptologie und Koptologie der Universität, 87-102.

Stephan, J. (2011) Die altägyptische Medizin und ihre Spuren in der abendländischen Medizingeschichte. Ägyptologie 1. Berlin: LIT Verlag.

Steuer, R. O. and Saunders, J. B. de C. M. (1959) Ancient Egyptian and Cnidian Medicine: The Relationship of Their Aetiological Concepts of Disease. Berkeley/Los Angeles: University of California Press.

Stol, M. (2004) ‘An Assyriologist Reads Hippocrates', in Horstmanshoff, H. F. J. and Stol, M. (eds.) Magic and Rationality in Ancient Near Eastern and Graeco-Roman Medicine. Leiden/Boston: Brill, 63-78.

Tacke, N. (2001) Verspunkte als Gliederungsmittel in ramessidischen Schülerhandschriften. Studien zur Archäologie und Geschichte Altägyptens 22. Heidelberg: Heidelberger Orientverlag.

Thomas, R. (2004) 'Greek Medicine and Babylonian Wisdom: Circulation of Knowledge and Channels of Transmission in the Archaic and Classical Periods', in Horstmanshoff, H. F. J. and Stol, M. (eds.) Magic and Rationality in Ancient Near Eastern and GraecoRoman Medicine. Leiden/Boston: Brill, 175-85.

Verhoeven, U. (2001) Untersuchungen zur späthieratischen Buchschrift. Orientalia Lovaniensia Analecta 99. Leuven: Peeters.

Von Deines, H. and Grapow, H. (1959) Grundriss der Medizin der alten Ägypter VI. Wörterbuch der ägyptischen Drogennamen. Berlin: Akademie-Verlag.

Von Deines, H. and Westendorf, W. (1961-62) Grundriss der Medizin der alten Ägypter VII 1-2. Wörterbuch der medizinischen Texte. Berlin: Akademie-Verlag.

Walker, J. H. (1996) Studies in Ancient Egyptian Anatomical Terminology. The Australian Centre for Egyptology Studies 4. Warminster: Aris and Phillips.

Westendorf, W. (1999) Handbuch der altägyptischen Medizin. Handbuch der Orientalistik, Abteilung 1. Der Nahe und Mittlere Osten 36. 2 Vol. Leiden/Boston/Köln: Brill.

\section{Electronic resource}

Cuneiform Digital Library Initiative (CDLI) (https://cdli.ucla.edu) (Accessed 7 July 2017). 